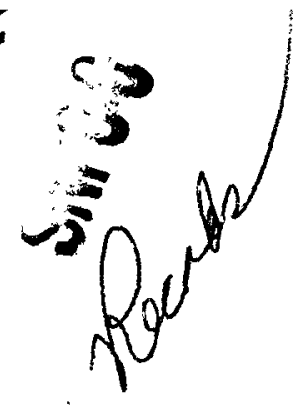

ADDENDUM TO WANEF OPERATING IIMITS, WANL-TME-383

WANL-TME-643

December 30, 1963

Prepared by

W. P. Kovacik

W.P. Kowacik

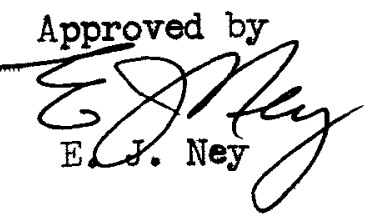

Approved by

T. A Kateaced fos
FILE COPY $\$ 2$ Return to REON

Technical Information Center Aerojet-General Corporation This report was prepared as an account of work che United States nor the United States Atomic Ener Commission, nor Commission, nor any of therr employees, nor any of their contractors, subcontractors, or their employees,

makes any warranty, express or implied, or assumes any

gal liability or responsibility for the accuracy, com-

pleteness or usefulness of any information, apparatus,

product or process disclosed, or represents that its use

would not infringe privately owned rights.

\title{
INFORMATION CATEGORY
}

\section{MASTER}

UNCLASSIFIED

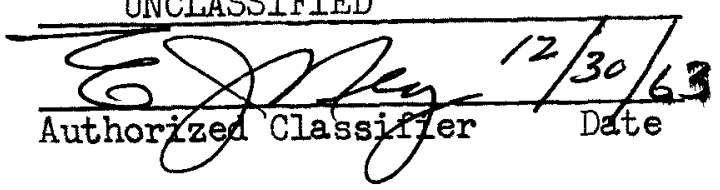




\section{DISCLAIMER}

This report was prepared as an account of work sponsored by an agency of the United States Government. Neither the United States Government nor any agency Thereof, nor any of their employees, makes any warranty, express or implied, or assumes any legal liability or responsibility for the accuracy, completeness, or usefulness of any information, apparatus, product, or process disclosed, or represents that its use would not infringe privately owned rights. Reference herein to any specific commercial product, process, or service by trade name, trademark, manufacturer, or otherwise does not necessarily constitute or imply its endorsement, recommendation, or favoring by the United States Government or any agency thereof. The views and opinions of authors expressed herein do not necessarily state or reflect those of the United States Government or any agency thereof. 


\section{DISCLAIMER}

Portions of this document may be illegible in electronic image products. Images are produced from the best available original document. 


\section{ABSTRACT}

A change to the Westinghouse Astronuclear Experimental Facility (WANEF) Operating Limits has become necessary for operational reasons. The change has been reviewed and approved by the WANL Nuclear Safety Committee and is presented herein as required by Section III D 3 of WANL-TME-383, WANEF Operating Limits, and Chapter 7, Section 7.4.1a of WANL-TNR-099, WANEF Safety Report. 


\section{Introduction}

In accordance with part 7.4.Ia (Authorization of Tests or Modifications) of WANEF Safety Report (WANL-TNR-099), it has been proposed to the WANL Nuclear Safety Comittee that the present voltage supplies (both H.V. and compensation) for the PAX/PTX ion chambers be replaced with equivalent dry cell batteries. Furthermore, it was recommended that, with the use of battery supplies, the H.V. failure scrams be removed from the system. These changes have been reviewed and approved by the WANL Nuclear Safety Committee. 


\section{Conclusion}

It is concluded that the proposed change to the WANEF nuclear instrumentation will not increase the probability or magnitude of the previously considered hazards of WANL-TNR-099, WANEF Safety Report. 
WANL-TME-643

\section{Discussion}

The present voltage supplies, which are electronic in nature, have exhibited both a high failure rate and noisy operation. Considerable effort has been expended to date in attempting to improve the situation. Transfer of the power supplies from the console to the test cell has reduced the cable runs by about 100 feet and has resulted in considerable reduction in noise in the neutron channels. However, noise originating in the electronic supplies still exists which reduces the actual sensitivity and responses of the neutron channels. This is so because a larger amount of damping and a higher full scale scram must be selected for the log and linear amplifiers, respectively, in order to reduce the number of noise induced scrams. Furthermore, the high failure rate of the electronic H.V. supplies can result in operational delays.

The use of battery packs for high and compensation voltage supplies is an accepted system at other government and licensed critical facilities. Because of the very low current drain by the ion chambers, the dry cells have essentially a shelf lifetime. On-line failures of battery supplies are very improbable, thus eliminating the need of $\mathrm{H} . \mathrm{V}$. failure scrams. Demonstration of channel response during checkout coupled with monthly or bi-monthly battery checks would fully insure the reliability of this system.

The modification would involve the use of compact dry cell battery packs mounted on or near the ion chambers and connected to them through short runs of cable. The failure scrams for the ion chamber high voltage supplies would be removed from the scram system. 
The proposed change will affect WANL-TME-383, "WANEF Operating Limits," at the following locations.

1. Table 3, Scram Conditions, page III-11. Delete reference to Ion Chamber High Voltage Supply.

2. Table 4, Operational Status Indicators, page III-12. Delete 1tem 3. Delete item 7 .

Therefore, in accordance with Chapter 7, Section 7.4 of WANL-TNR-099, "WANEF Safety Report," and Section III D 3 of WANL-TME-383, this change is presented for approval.

Other documentation changes required will be incorporated into the WANEF master copies and transmitted as periodic revised issues. 